\title{
Ambiances
}

anbiances Environnement sensible, architecture et espace urbain Redécouvertes | 2020

\section{Jean-François Augoyard, an explorer of the sensory world}

Jean-Paul Thibaud

Translator. Sophie Provost

\section{OpenEdition}

\section{Journals}

Electronic version

URL: http://journals.openedition.org/ambiances/3126

DOI: $10.4000 / a m b i a n c e s .3126$

ISSN: 2266-839X

Publisher:

Direction Générale des Patrimoines - DAPA - MCC, UMR 1563 - Ambiances Architectures Urbanités (AAU)

\section{Electronic reference}

Jean-Paul Thibaud, « Jean-François Augoyard, an explorer of the sensory world », Ambiances [Online], Rediscovering, Online since 13 October 2020, connection on 15 October 2020. URL : http:// journals.openedition.org/ambiances/3126; DOI : https://doi.org/10.4000/ambiances.3126

This text was automatically generated on 15 October 2020

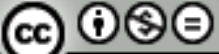

Ambiances is licensed under a Creative Commons Attribution-NonCommercial-NoDerivatives 4.0 International License. 


\title{
Jean-François Augoyard, an explorer of the sensory world
}

\author{
Jean-Paul Thibaud \\ Translation : Sophie Provost
}

\section{EDITOR'S NOTE}

Text translated from French by Sophie Provost

1 Jean-François Augoyard is senior researcher at CNRS (France). After studying philosophy (research on Giordano Bruno), aesthetics and musicology (Conservatoire National of Lyon and Gregorian Institute), he started teaching in the French national education system. He then carried out his doctorate in urban studies and practiced urban planning in Paris. In 1975, he started a new path as a researcher in urban sociology and environmental anthropology, while he continued teaching in several universities (Vincennes, Paris VI, Grenoble 2), and at the Graduate School of Architecture of Grenoble since 1976. In collaboration with Jean-Jacques Delétré, he created the Centre de recherche sur l'espace sonore (CRESSON - https://aau.archi.fr/ cresson) in 1979. Along with Jean-Pierre Peneau, he also created the Ambiances architecturales et urbaines Joint Research Unit (UMR - CNRS/Ministry of Culture) in 1998. He is co-director of a French doctoral programme on architectural and urban ambiances. Moreover, Jean-François Augoyard edited the "Ambiance, ambiances" collection for the A la Croisée Editions (9 books).

2 His main studies revolve around the perception of space and social conducts in the city, around the interdisciplinary methodology of the sensory environment (sound, light, smells), around the theory of architectural and urban ambiances and around the aesthetic experience in an urban milieu ${ }^{1}$. In France or abroad, he is an expert and member of several scientific or academic committees on the urban environment, landscape, public space and on the relations between art and city. 
Inventive researcher and pioneer in several fields of urban research, Jean-François Augoyard holds a special place in French social science. As Pascal Amphoux and Philippe Le Guern mention it (2017): "Jean-François Augoyard belongs to a generation of pioneers who brought new objects and conceived new paradigms to re-think the social matter, and who also structured the research field by pushing the academic boundaries". Trained in philosophy by thinkers as varied as Henri Maldiney and Gilles Deleuze, he has been since early on committed to combine theoretical work and field survey, opening to new realms of thought and meticulous investigation on the ordinary urban experience. Avoiding the trends of the 1970s - whether it was structuralism, marxism or the semiotics of space - he developed an original position, which will be the foundation of the CRESSON scientific program, as well as current questions on architectural and urban ambiances.

\section{The Step-by-step opening}

4 Jean-François Augoyard made himself known with a first book, in 1979: Pas-à-pas, essai sur le cheminement en milieu urbain ${ }^{2}$. Stemming from his doctoral thesis, defended in 1976 at the Université des Sciences Sociales of Grenoble, this book was part of a collective research dynamic that was particularly thriving at the time in Grenoble, at the crossroads between urban sociology and theories of social imagination ${ }^{3}$. With this seminal work, Jean-François Augoyard has paved his way by studying in an original way the dwelling practices in Villeneuve, Grenoble. This is not the place for an extensive presentation of this reference book ${ }^{4}$, and I will only mention here the most important points.

Firstly, we should note that we are dealing with a research work that revolves around the urban everyday life and the ordinary dwelling experience. If this undertaking has affinities with other leading thinkers - we can think for example about Pierre Sansot's poetics of space, about Henri Lefebvre's critique of everyday life, Erving Goffman's staging of everyday life, Georges Pérec's infra-ordinary or Michel de Certeau's invention of the everyday - it remains different by proposing an approach that was until then unprecedented, rooted in phenomenology and rhetoric, and by putting to the test a demanding and large-scale empirical work. The concept of ordinary is thus tackled as close as possible to the lived dwelling experience and contexts.

6 To that end, secondly, Jean-François Augoyard introduces the theme of urban walks within the observation of dwelling conducts. He initiates a set of works that will be developed at a later stage. Along with the traditional research subjects in social studies - work, leisure, consumption - walking now finds a place in social science. It has not stopped being studied ever since. It is thanks to an acute attention to figures of walking and to the moving bodies that this work has a large-scale theoretical scope.

Thirdly, this thorough situated observation work gives grounds for the discovery of a true rhetoric of dwelling, which will be at the heart of the Step-by-step project. Against an all-too deterministic sociology, this research opens to a way of thinking modalities that would eventually affect in a sustainable way the body of work carried out at CRESSON. By being located at the level of the expression of the inhabitants, and by describing in detail the different figures of walking, the now classic concept of "ways of dwelling" emerges and unfolds. In other words, the point here is to thematise the question of how and to ask ourselves "how things occur". 
8 This new research orientation is also possible by the implementation of an original investigatory mechanism, which gives their rightful place to the description, narrative and memory of the future. The creation of the "narrative conduct" (conduite de récit) - a method that articulates language expression and wandering practices - also has an essential role in the empirical testing of the pathway rhetoric. It also initiates a set of methodological innovations that, from then on, will continuously appear in JeanFrançois Augoyard and the CRESSON team's investigations (we will go back to this question regarding studies dedicated to the sound environment).

9 Lastly, although it was not thematised as such, the theme of ambiances can be seen as underlying the Step-by-step project. The attention given to the sensorial motricity in action, to the pathic dimension of experience, to atmospheric effects and to the climate pervasiveness raises many questions, which will be at the centre of some future works on ambiances. The references to Henri Maldiney, Maurice Merleau-Ponty or Ludwig Binswanger's studies are no coincidence, as each one contributes in his own way to foresee this new realm of thought.

\section{The ordinary of sound}

As we understood, Step-by-step represents a seminal work that adopts a new scientific position, outlines a long-term research programme and foreshadows CRESSON's future research works. However, it is only the first entry into Jean-François Augoyard's scientific journey. Indeed, a fundamental side of the problem statements developed afterwards deals with the sonic environment. CRESSON - Centre de Recherche sur l'Espace Sonore (in its first designation) - clearly states the special interest given to this sensory modality. Without going into detail on 40 years of research on that topic ${ }^{8}$, sound here becomes both a field of empirical investigation and a specific way to question architecture, urbanity, sociability and environment. This field of research will represent the opportunity to develop a true interdisciplinary approach, at the crossroads between social science, design science and applied physical science.

11 In 1978, an exploratory study was carried out ${ }^{9}$, questioning the dwelling practices through sound phenomena and reproducing a modal approach from this new field of study. This research report is unfortunately little known ${ }^{10}$ but essential, and it operates in a way the passage from Step-by-step to the future works on sound. Many arguments and lines of research emerged at this point, proposing the opening of a third path between music and noise, questioning the idea of sound territoriality. It proposed an alternative approach to the concept of soundscape, introducing an ethological perspective, thematising the sound imagination and focusing on the phonic activity ${ }^{11}$. Those represent many open lines of research that would inform 40 years of research at CRESSON on the sound world.

12 The foundations of a background research work on the ordinary situated sound experience were set. They came to fruition later with other research works and different themes: exploratory research on the concept of sound effect, opening up to a broadened interdisciplinary approach ${ }^{12}$, research on sound environment and interpersonal communication, questioning the immanence of sociality ${ }^{13}$, research on the production of the sound environment, asserting the importance of listening attitudes and ways of sounding ${ }^{14}$, research on information sources regarding neighbourhood noise, questioning the idea that "the noise is the other" ${ }^{15}$, research on 
the sensorial factors of the sense of insecurity, testing both the sound and light aspects $^{16}$. Always strengthened by field data and interdisciplinary empirical investigations, these studies, forerunners to Sound studies, definitely anchor the theoretical and epistemological position implemented at CRESSON. Moreover, we can add that new investigation methods would later emerge thanks to these works, whether it is for example on the reactivated listening interviews ${ }^{17}$ or the anecdote repository.

13 A long-term collaboration, led by Jean-François Augoyard and carried out by the CRESSON team, will focus on the concept of sound effect ${ }^{18}$. No fewer than around sixty sound effects were recorded and described in an interdisciplinary way, offering a sound grammar of constituents regarding our everyday listening. Halfway between the sound object and the soundscape ${ }^{19}$, the concept of sound effect represents the cornerstone of the whole body of work regarding sound, as well as the bond of a shared culture within the team.

14 The growing power of research on sound environment in France would bring JeanFrançois Augoyard to carry this theme at a national level. He thus organised a largescale, bi-annual seminar questioning the articulation between sound and societal, gathering the best specialists on the subject ${ }^{20}$. A few years later, a pluridisciplinary symposium was organised at CRESSON, on the sound quality of inhabited spaces, bringing together acousticians, architects and sociologists ${ }^{21}$. A synthesis article was published afterwards ${ }^{22}$, taking stocks on the origin, development and evolution of the French research around the theme of urban sound environment.

\section{The aesthetics of ambiances}

In parallel with the work on sound, which continues to be developed at CRESSON, the early 1990s see Jean-François Augoyard introducing, in collaboration with Jean-Pierre Peneau from CERMA at the Graduate Architecture School of Nantes, the theme of architectural and urban ambiances ${ }^{23}$.

16 Two main orientations, intrinsically connected, are implemented in Jean-François Augoyard's studies in terms of ambiances.

On one side, it is a question of developing a theory of architectural and urban ambiances over time. Since the 1990s, a true scientific and epistemological framing work has been undertaken, opening this new field of research. An article of great importance was published in 1994, initiating and aiming to establish scientifically this emerging field of investigation ${ }^{24}$. Many other publications followed, continuously developing, bolstering and specifying the theoretical project over time ${ }^{25}$. There is no way to try and summarise the scope, the complexity and the subtlety of this proposition. Therefore, we will simply mention a few aspects particularly prominent: distinction between ambiance in the singular (as an overall quality that is experienced) and ambiances in the plural (as defined in the various fields of applied physics); affirmation of the phenomenon as the central theme of the analyses; recognition of physical signals resulting in contextual physics ${ }^{26}$, emphasis on the fundamentally situated, inter-sensorial and social nature of the sensoryexperience; proposition of a true interdisciplinary approach based on transversal methods and tools crossreferencing social science, design science and applied physical science; importance given to the built environment and to the stakes of architectural and urban design; 
articulation between the receptive and the generative dimensions of ambiances. These arguments contribute to meticulously build this new field of study, making JeanFrançois Augoyard one of the main instigators of French research in this subject area. In 2008 in Grenoble, the organisation of the Faire une ambiance symposium confirms that he is at the centre of the development and structuring of this field ${ }^{27}$.

On the other side, the theory of ambiances developed by Jean-François Augoyard is deeply intertwined with an aesthetic questioning in nature ${ }^{28}$. It seems as if the theory of ambiances and the aesthetics of ambiances go together and are inseparable. The article translated and published here is evidence, highlighting an original conception of sensory perception and the possibility of an aesthetics of ambiances. It also aims to revisit the field of aesthetics itself by turning ambiances and atmospheres its key lever. A sensible and articulated reading of the great aesthetic thoughts enables an original version on this matter. Furthermore, questioning ambiances is paired with a socioaesthetic approach that will be supported by large-scale empirical studies regarding artistic actions in the urban environment and the ordinary aesthetic experience of architecture ${ }^{29}$. Therefore, the point is to both propose an aesthetic problem statement within ambiances - as the fundamental and constitutive question for the field - and test this proposition against field investigations. Such an aesthetics of ambiances thus finds ways to be supported in an empirical way, becomes a part of the current everyday life and work as a true analyser of the contemporary sensory transformations. As we have shown, Jean-François Augoyard opened the field of ambiances to architectural and urban research while paving his own way from an aesthetic problem statement in nature.

What could be better for the reader than to read this translated and revisited version of one of Jean-François Augoyard's essential articles? There is no doubt that it is a fascinating text written by a tireless navigator of the sensory world...

\section{BIBLIOGRAPHY}

Amphoux, Pascal \& Le Guern, Philippe. 2017. Le temps des pionniers : Jean-François Augoyard et le Cresson (Entretien recueilli par Pascal Amphoux et Philippe Le Guern). Politiques de la communication, hors-série $\mathrm{n}^{\circ} 1, \mathrm{p} .31-44$.

Augoyard, Jean-François. 1978. Les pratiques d'habiter à travers les phénomènes sonores. Paris: ESA/ Plan Construction.

Augoyard, Jean-François. 2010 [1979]. Pas à pas. Essai sur le cheminement quotidien en milieu urbain. Bernin: A la Croisée.

Augoyard, Jean-François. 1980a. Répons pour voix discrètes et trois silences. Traverses, ํㅡㄹ 20, p. 133-141.

Augoyard, Jean-François. 1980b. «L'invention Phonurgique Ordinaire » In: Scheer, Elisabeth (ed.). Paysage sonore urbain : Deux journées d'exposition d'écoute et de communications. Paris: PlanConstruction. p. 233-241. 
Augoyard, Jean-François. 1982a. Expression et marque dans le vécu sonore. In: Centre de création industrielle ; Centre Georges Pompidou (eds.). L'Oreille Oubliée, Paris: Centre Georges Pompidou. p. 56-59.

Augoyard, Jean-François. 1982b. De l'intermédiaire et du modal dans les situations quotidiennes. In: AISLF (ed.). Milieu et rapport social. Actes des journées d'Etudes de Saint-Etienne. Bruxelles. p. 72-83. Augoyard, Jean-François. 1985. Les allures du quotidien. Temps Libre, 12. p. 49-60.

Augoyard, Jean-François. 1987. Séminaire de recherche environnement sonore et société (1984-1986) : résumé synthétique des travaux. Grenoble: CRESSON. Rapport de recherche 11.122 pages.

Augoyard, Jean-François. 1989a. Passo passo: Il percorso quotidiano in ambiente urbano. Roma: Edizioni del Lalvoro.

Augoyard, Jean-François. 1989b. Contribution à une théorie générale de l'expérience sonore : le concept d'effet sonore. Revue de musicothérapie, 9 (3). p. 18-36.

Augoyard, Jean-François. 1991a. Les qualités sonores de la territorialité humaine. Architecture et comportement, 7(1). p. 13-23.

Augoyard, Jean-François 1991b. La compétence sociale du regard esthétique. In. Plan Urbain (ed.). L'espace du public : les compétences du citadin. Editions Recherches. p. 41-46.

Augoyard, Jean-François. 1994. Actions artistiques en milieu urbain. A l'écoute d'une épiphanie sonore. Étude d'accompagnement de l'action sur l'environnement sonore urbain de Nicolas Frize à Saint Denis entre 1991 et 1993. Grenoble: CRESSON. Rapport de recherche $42 a .53$ pages.

Augoyard, Jean-François. 1995a. L'environnement sensible et les ambiances architecturales. Espace Géographique, 4. p. 302-318.

Augoyard, Jean-François. 1995b. La vue est-elle souveraine dans l'esthétique paysagère ? In: Roger, Alain (ed.). La théorie du paysage en France (1974-1994). Paris: Champ-Vallon. p. 334-345.

Augoyard, Jean-François. 1998a. The Cricket Effect. Which tools for the research on sonic urban ambiences? In: Karlsson, Henrik (ed.). From Awareness to Action: Proceedings from "Stockholm, Hey Listen!" Conference on acoustic ecology, Stockholm, June 9-13 1998. Stockholm: The Royal Swedish Academy of Music, in partnership with The World Forum for Acoustic Energy, Stockholm-Cultural Capital of Europe '98, World Health Organization. p. 116-125.

Augoyard, Jean-François. 1998b. Éléments pour une théorie des ambiances architecturales et urbaines. Les Cahiers de la recherche architecturale, 3 (42-43). p. 7-23.

Augoyard, Jean-François. 1999. L'objet sonore ou l'environnement suspendu. In: Bayle, François \& Dufour, Denis (eds.) Oür, entendre, écouter, comprendre après Schaeffer. Paris: INA-GRM/BuchetChastel. p. 83-106.

Augoyard, Jean-François. 2000a. Du bruit à l'environnement sonore urbain. Evolution de la recherche française depuis 1970. In: Pumain, Denise \& Mattei, Marie-Flore (eds). Données urbaines $N^{\circ}$ 3. Paris: Anthropos. p. 397-409.

Augoyard, Jean-François. 2000b. L'action artistique dans l'espace urbain. In: Metral, Jean (ed.). Culture en ville. La Tour-d'Aigues: Editions de L'Aube. p. 14-23.

Augoyard, Jean-François. 2001. L'entretien sur écoute réactivée. In : Grosjean, Michèle \& Thibaud, Jean-Paul (eds.) L'espace urbain en méthodes. Marseille: Editions Parenthèses. p. 127-153.

Augoyard, Jean-François. 2003. Une sociabilité à entendre. Espaces et Sociétés, 115. p. 25-42. 
Augoyard, Jean-François. 2004. Vers une esthétique des ambiances. In: Amphoux, Pascal Amphoux; Thibaud, Jean-Paul Thibaud \& Chelkoff, Grégoire (eds.) Ambiances en débats. Bernin, Editions à la Croisée, 2004. p. 17-30.

Augoyard, Jean-François. 2005. Une physique contextuelle des ambiances urbaines. Culture et recherche 104. p. 21-22.

Augoyard, Jean-François. 2007. A comme Ambiance(s). Cahiers de la recherche architecturale et urbaine 20/21. p. 33-37.

Augoyard, Jean-François. 2007. Step by Step. Everyday Walks in a French Urban Housing Project (translated by David Ames Curtis, foreword by Françoise Choay, afterword by David Ames Curtis). Minneapolis: University of Minnesota Press.

Augoyard, Jean-François. 2008. La construction des atmosphères quotidiennes : l'ordinaire de la culture. Culture et recherche 114/115. p. 58-60.

Augoyard, Jean-François. 2011. Faire une ambiance ? Conférence inaugurale. In: Augoyard, JeanFrançois (ed.). Faire une ambiance, Creating an atmosphere : Actes du colloque international, Grenoble, 10 - 12 septembre 2008. Grenoble: CRESSON. p. 17-35.

Augoyard, Jean-François. 2015. La ville sonnante. In Tixier, Nicolas (ed.). Traversées Urbaines : villes et films en regard. Genève: MetisPresses. p. 91-94.

Augoyard, Jean-François. 2016. L'apparaître des ambiances. In : Rémy, Nicolas \& Tixier, Nicolas (eds.). Ambiances, tomorrow. Proceedings of the 3rd International Congress on Ambiances, Vol. 02, Volos, 21 - 24 september 2016. Grenoble/Volos: Ambiances International Network \& University of Tessaly. p. 579-585.

Augoyard, Jean-François; Amphoux, Pascal \& Balaÿ, Olivier. 1985. Environnement sonore et communication interpersonnelle, Tome 1 et Tome 2. [Rapport de recherche] 07. Grenoble: CRESSON, CNT. 132 et 93 pages.

Augoyard, Jean-François; Amphoux, Pascal \& Chelkoff, Grégoire. 1985. La production de l'environnement sonore : analyse exploratoire sur les conditions sociologiques et sémantiques de la production des phénomènes sonores par les habitants et usagers de l'environnement urbain. Grenoble: CRESSON. Rapport de recherche 06. 189 pages.

Augoyard, Jean-François; Balaÿ, Olivier; Belle, Olivier \& Chelkoff, Grégoire. 1982. Sonorité, sociabilité, urbanité : méthode pour l'établissement d'un répertoire des effets sonores en milieu urbain. Grenoble: AGRA - Laboratoire de recherche sur l'espace sonore. 155 pages + 15 annexes.

Augoyard, Jean-François \& Leroux, Martine. 1992. Les facteurs sensoriels du sentiment d'insécurité. In: Bernard, Yvonne \& Segaud, Marion (eds.). La ville inquiète : habitat et sentiment d'insécurité. La Garenne-Colombes: Ed. de l'Espace Européen. p. 23-51.

Augoyard, Jean-François; Leroux, Martine Leroux; Aventin, Catherine \& Augoyard, Erwan. 2003. L'expérience esthétique ordinaire de l'architecture. Parcours en espace public. Rapport de recherche 57 (2 vol.). Grenoble: CRESSON. 180 and 342 pages.

Augoyard, Jean-François \& Leroux, Martine, avec Aventin, Catherine; Augoyard, Julie \& Pernice, Didier. 1999. Médiations artistiques urbaines. Rapport de recherche 42b. Grenoble: CRESSON. 207 pages.

Augoyard, Jean-François; Medam, Alain Medam; Pessin, Alain \& Torgue, Henry. 1975. L'urbain à l'action. L'urbain du savoir à Grenoble, Grenoble: UER Aménagement et urbanisation. 
Augoyard, Jean-François \& Torgue, Henry (éds.) À l'écoute de l'environnement : répertoire des effets sonores. Marseille: Editions Parenthèses. 1995.

Augoyard, Jean-François \& Torgue, Henri (eds.) 2003. Repertorio degli effetti sonori. Torino: LIM.

Augoyard, Jean-François \& Torgue, Henri (eds.). 2005. Sonic Experience: A Guide To Everyday Sounds. Montreal: McGill-Queen's University Press.

Buyck, Jennifer; Martin, Samue; Prévot, Maryvonne \& Romano, Fleur. 2018. Genèse des formations en urbanisme en France : Grenoble un "laboratoire urbain" pas comme les autres? Territoire en mouvement Revue de géographie et aménagement [online]. Available online at: http:// journals.openedition.org/tem/4773 (consulted on September 27, 2018)

de Certeau, Michel. 1984. The practice of everyday life. Berkeley: University of California Press.

Chelkoff, Grégoire. 2010. Pour une conception modale des ambiances architecturales. Faces Journal d'architecture 67. p. 18-23.

Chelkoff, Grégoire. 2013. L'homme sonore en contexte urbain - Les trente premières années du CRESSON. In: Candau, Joël \& et Le Gonidec, Marie Barbara (eds.). Paysages sensoriels : essai d'anthropologie de la construction et de la perception de l'environnement sonore, Aubervilliers: Editions du Comité des travaux historiques et scientifiques. p. 177-196.

CRESSON (ed.) 1992. La qualité sonore des espaces habités / Sonic quality in the living environment. 20 22 march 1992, Grenoble. Grenoble: CRESSON.

Jacob, André. 1980. Jean-François Augoyard, Pas à pas. Essai sur le cheminement quotidien en milieu urbain. L'Homme et la société 55-58. p. 296.

Leroux, Martine Leroux \& Augoyard, Jean-François. 1986. Les sources d'informations sur les bruits de voisinage. Grenoble: CRESSON. Rapport de recherche 08.51 pages and appendix.

Sevin, Jean-Christophe \& Voilmy, Dimitri. 2009. Une pensée de la modalité. Entretien avec JeanFrançois Augoyard. Ethnographiques.org 19 [online]. Available online at: https:// www.ethnographiques.org/2009/Augoyard-Sevin-Voilmy (consulted on April 20, 2020).

Thibaud, Jean-Paul. 2016. Le sonore dans tous ses états. Quarante ans de recherche au Cresson. In: Aterianus-Owanga, Alice \& Santiago, Jorge (eds.). Aux sons des mémoires. Musiques, mémoires, archives. Lyon: Presses Universitaires de Lyon. p. 147-172.

Winkin, Yves. 2010. Relire Pas-à-pas aujourd'hui. In : Thomas, Rachel (ed.) Marcher en ville : faire corps, prendre corps, donner corps aux ambiances. Paris: Éditions des archives contemporaines. p. 21-28.

\section{NOTES}

1. For more information on Jean-François Augoyard's scientific production, please visit: https:// aau.archi.fr/equipe/augoyard-jean-francois/. I only mention a part of his substantial production, which spans over forty years. I would like to thank Françoise Acquier, reference librarian at CRESSON, for her outstanding work that now allows to directly access the team members' production, including that of Jean-François Augoyard.

2. This book was reissued in French in 2010 by the A la Croisée Editions, with a foreword by Yves Winkin. It was also translated into English and published by the University of Minnesota Press in 2007 (Step by step - Everyday walks in a French Urban Housing Project), with a foreword written by Françoise Choay and an afterword by David Ames Curtis. An Italian translation was published in 
1989 by Edizioni del Lavoro. It was called Passo passo. Lastly, several chapters were translated into German by Justin Winckler, in an upcoming book.

3. Among the researchers who have actively contributed to the rise of the Grenoble research in social science in the 1970s-1980s, we can mention François Ascher, Yves Chalas, Gilbert Durand, Alain Médam, Alain Pessin, Pierre Sansot, and Henry Torgue. For more information on the history of this urban laboratory, see Buyck, Martin, Prévot \& Romano (2018). For an illustration of this collective urban research, see the research report by Augoyard, Médam, Pessin \& Torgue (1975).

4. This book was commented upon its publication - see for example André Jacob's report, published in 1980 - and keeps being commented upon - see for example the enlightening article written by Yves Winkin (2010). It will hold a very special place in Michel de Certeau's work, in particular in The Practice of Everyday Life (translation published in 1984).

5. See Augoyard (1985) in particular.

6. On this modal approach, you can refer to Jean-François Augoyard's interview by JeanChristophe Sevin and Dimitri Volley (2009). See also Augoyard (1982b). To continue on this research position, see the article by Grégoire Chelkoff (2010) on a model conception of architectural ambiances.

7. See Augoyard (2001)

8. For an overview of the CRESSON's work on soundscape, see Chelkoff (2013) and Thibaud (2016).

9. See Augoyard (1978)

10. The document is now accessible online, on the halts platform, see: https://halshs.archivesouvertes.fr/halshs-00685590/

11. Several articles unfold and further the results from this initial research later on. See in particular Augoyard, (1980a, 1980b, 1982a, 1991a, 1995b).

12. See Augoyard, Balaÿ et al. (1982)

13. See Augoyard, Amphoux \& Balaÿ (1985). A synthesis article highlighting the concept of "sound parasite" is also available in: Augoyard (2003).

14. See Augoyard, Amphoux \& Chelkoff (1985).

15. See Leroux \& Augoyard (1986).

16. See Augoyard \& Leroux (1992).

17. For more information on the interview on reactivating listening, see Augoyard (2001). The anecdote repository was experimented during the aforementioned study on sound environment and interpersonal communication.

18. For a summarised presentation of this concept, see Augoyard (1989b). An article is also available in English (Augoyard, 1998a). The outcome of the collective work on the concept of sound effect became the repository of sound effects (Augoyard \& Torgue, 1995), translated and published in Italian (Augoyard \& Torgue, 2003) and in English (Augoyard \& Torgue, 2005). The concept of sound effect was also applied to film analysis, see Augoyard (2015) for more information.

19. See Augoyard (1999)

20. Since 1984, the Environnement sonore et société seminar has been initiating a background prospective work on this emerging theme. See Augoyard (1987).

21. See CRESSON (1992)

22. See Augoyard (2000a)

23. This new theme is at the origin of the reunion of CRESSON and CERMA as on UMR called " Ambiances Architecturales et Urbaines", as well as a degree of the same name, which was to train a whole generation of young researchers in the 1990s.

24. See Augoyard (1995a)

25. In particular, Augoyard (1998b, 2004, 2007, 2008, 2011, 2016)

26. On the topic of the contextual physics of ambiances, see Augoyard (2005). 
27. The opening conference, followed by its publication in the proceedings of the symposium (Augoyard, 2011), represents an important step in Jean-François Augoyard's work.

28. The aesthetic question has been developed since the beginning of the 1990s. See for example Augoyard (1991b), until his most recent works (Augoyard, 2016).

29. Various publications of these field investigations and results are available. See Augoyard (1994), Augoyard \& Leroux (1999); Augoyard, Leroux, Aventin et al. (2003). Among the main researchers taking part in this work, we can mention Martine Leroux and Catherine Aventin. Beside these various research reports, we can also mention a synthesis article on the subject (Augoyard, 2000b).

\section{AUTHORS}

\section{JEAN-PAUL THIBAUD}

Jean-Paul Thibaud, sociologist, is CNRS senior researcher at Cresson - Research Center on Sonic Space and the Urban Environment, UMR Ambiances Architectures Urbanités. His field of research covers the theory of urban ambiances, ordinary perception in urban environment, sensory culture and ethnography of public places, anthropology of sounds, qualitative in situ methodology. He has directed the CRESSON research lab and has founded the International Ambiances Network. Jean-Paul Thibaud has published numerous papers on urban ambiances and has co-edited several books on this field of research: https://cv.archives-ouvertes.fr/jean-paulthibaud. His latest book: En quête d'ambiances. Eprouver la ville en passant (Genève,

MétisPresses, 2015). 